\title{
Chemical Characteristics of Goat Cheese with Different Percentages of Mixed Indigenous Probiotic Culture during Ripening
}

\author{
T. Setyawardani*, A. H. D. Rahardjo, \& M. Sulistyowati \\ Department of Animal Production, University of Jenderal Soedirman, \\ Jalan Dr. Soeparno No. 60, Karangwangkal, Purwokerto, Jawa Tengah 53123, Indonesia \\ (Received 10-11-2016; Reviewed 27-12-2016; Accepted 23-02-2017)
}

\begin{abstract}
This research was aimed to study the chemical characteristic of goat cheese that used various concentrations of probiotic starter with combinations of Lactobacillus rhamnosus TW2 and Lactobacillus plantarum TW14 isolates. The experiment was conducted with a completely randomized design with a $4 \times 4$ factorial arrangement. The first factor was the concentration of probiotic starter consisted of 4 lavels i.e., 2.5, 5.0, 7.5, and $10 \% \mathrm{v} / \mathrm{v}$. All probiotic concentrations used the same ratio of $L$. rhamnosus TW2 and L. plantarum TW14, i.e. 1:1. The second factor was the duration of ripening process consisted of 4 levels i.e., 0 (no ripening), 10, 20, and 30 days at $5^{\circ} \mathrm{C}$. The observed variables were cheese chemical properties including water content, protein, fat, ash, $\mathrm{pH}$, total titratable acidity (TTA), free fatty acids (FFA), and proteolysis profile. The results showed that addition of probiotic starter at a concentration of $5 \%$ mixture of $L$. rhamnosus TW2 and L. plantarum TW14 increased $(\mathrm{P}<0.01)$ only on ash content. The duration of ripening process up to $30 \mathrm{~d}$ significantly increased $(\mathrm{P}<0.01)$ protein and fat. Combination of probiotic starter concentrations and duration of ripening process increased $(\mathrm{P}<0.01)$ fat and ash contents. Proteolysis profile showed that protein was degraded into 72 and $52 \mathrm{kDa}$ proteins, but no $17 \mathrm{kDa}$ protein was found in cheese ripened for $30 \mathrm{~d}$. It is concluded that $30 \mathrm{~d}$ duration of ripening at $5^{\circ} \mathrm{C}$ was the main contributing factor to chemical characteristics of cheese including chemical properties, $\mathrm{pH}$, TTA, FFA, and proteolysis profile of probiotic goat cheese, while the concentration of mixed probiotics affected ash content, TTA and FFA of cheese.
\end{abstract}

Keywords: Lactobacillus rhamnosusTW2, Lactobacillus plantarum TW14, cheese, starter, characteristics

\begin{abstract}
ABSTRAK
Penelitian bertujuan untuk mempelajari karakteristik kimiawi keju kambing yang diberi beberapa konsentrasi starter probiotik dengan campuran isolat Lactobacillus rhamnosus TW2 dan Lactobacillus plantarum TW14. Penelitian menggunakan metode eksperimental dengan rancangan acak lengkap pola faktorial berukuran $4 \times 4$. Faktor pertama adalah konsentrasi penambahan starter probiotik yang terdiri atas 4 level, yaitu 2,5; 5,0; 7,5; dan 10\% v/v dengan rasio 1:1 antara L. rhamnosus TW2 dan L. plantarum TW14. Faktor kedua ialah lama simpan yang terdiri atas 4 level, yaitu 0 (tanpa disimpan), 10, 20, dan 30 hari pada suhu $5^{\circ} \mathrm{C}$. Variabel yang diukur adalah karakteristik kimia keju, yaitu kadar air, protein, lemak, abu, $\mathrm{pH}$, total asam tertitrasi (TAT), asam lemak bebas (ALB), dan profil proteolisis. Hasil penelitian menunjukkan penambahan konsentrasi starter sebesar $5 \%$ campuran $L$. rhamnosus TW2 dan $L$. plantarum TW14 meningkatkan $(\mathbf{P}<0.01)$ kadar abu keju, sedangkan lama penyimpanan sampai dengan 30 hari meningkatkan $(\mathbf{P}<0.01)$ kadar protein dan lemak keju. Interaksi antara konsentrasi starter campuran dan lama penyimpanan yang berbeda meningkatkan $(\mathrm{P}<0.01)$ kadar lemak dan abu keju. Profil proteolisis menunjukkan bahwa pemecahan protein terjadi pada protein dengan BM 72 dan $52 \mathrm{kDa}$, sedangkan protein dengan BM $17 \mathrm{kDa}$ tidak mengalami pemecahan protein selama 30 hari penyimpanan. Dapat disimpulkan bahwa lama penyimpanan sampai dengan 30 hari pada suhu $5^{\circ} \mathrm{C}$ merupakan faktor utama yang mempengaruhi karakteristik kimiawi keju, yang meliputi komposisi kimia, pH, TAT, ALB, dan profil proteolisis keju kambing probiotik sedangkan konsentrasi campuran probiotik mempengaruhi kadar abu,TTA dan FFA keju.
\end{abstract}

Kata kunci: Lactobacillus rhamnosusTW2, L plantarum TW14, keju starter, karakteristik

${ }^{*}$ Corresponding author:

E-mail: trianasulistiono@gmail.com 


\section{INTRODUCTION}

Improving consumers' awareness on the importance of functional food has positively affected the development of healthy food products. Probiotic-enriched food product belongs to a functional food category. Probiotic is defined as a living organism that when it is given in a proper amount around $10^{5}-10^{7} \mathrm{CFU} / \mathrm{g}$ can give health benefits to the host (FAO/WHO, 2002). Some fermented products that contain probiotic are cheese, yoghurt, concentrate yoghurt, and kefir. Probiotic in cheese functions as a starter and it is within the cheese matrix during the ripening process. The use of probiotic strains as functional ingredients in dairy products offers health benefit to digestive tract in various conditions. Lactobacillus rhamnosus TW 2 and Lactobacillus plantarum TW 14 that were isolated from Ettawa goat milk (Setyawardani et al., 2011) belong to the group of in vitro and in vivo probiotics (Setyawardani et al., 2014).

Goat cheese is a product with a potential development as a functional food product because it is the source of macro nutrient substances and contains micro nutrients and bioactive peptide that highly beneficial for health (Korhonen \& Pihlanto, 2006). Cheese as a food is believed to have health benefits (Choi et al., 2012) due to the release of bioactive peptides during protein hydrolysis process and temperature treatment or microbial enzyme (Hafeez et al., 2014). The peptide has many benefits for health including antioxidant, antimicrobial, anti-hypertension, and so on (Nagpal et al., 2011).

During ripening, cheese will undergo physical, chemical, or microbiological changes. During the ripening process, the texture becomes smoother, consistency is solidified, the flavor is perfected, and the probiotic metabolite of Lactic Acid Bacteria (LAB) is optimally produced. Those changes are due to LAB interaction in the cheese matrix. Some researchers used probiotic with different strains, such as Himalayan cheese (Mushtaq et al., 2016), Scarmorza cheese (Guidone et al., 2015), and Minash freshcal cheese (Dantas et al., 2016).

Temperature and duration of ripening affect the outcome characteristics of cheese. Ripened at different temperatures, cheese will undergo change in $\mathrm{pH}$ value, $\mathrm{LAB}$ viability, and proteolysis process. The $\mathrm{pH}$ of the product tends to decrease because of metabolic activity of probiotic LAB. During proteolysis, peptides and proteins dissolve into simple amino acids that serve in forming the flavor and texture of the cheese. Probiotics can survive during the ripening and processing and does not produce unusual aroma and texture (Albenzio et al., 2013).

This research was designed to study the chemical characteristic of goat cheese produced by using various durations of ripening and concentrations of probiotic starter with mixture of isolates L. rhamnosus TW2 and L. plantarum TW14.

\section{MATERIALS AND METHODS}

This experiment used goat milk derived from Ettawa grade (PE) in breeding and production center of PE goat, PEGUMAS, in Central Java, Indonesia, while the probiotic culture of L. rhamnosus TW2 and $L$. plantarum TW14 were isolated by following the method used by Setyawardani et al. (2011). Commercial animal rennet, microbiology media of MRSB (deMan Rogosa and Sharpe Broth), Phosphate Buffer Saline (PBS), and chemicals were collected for laboratory analysis. The equipments were tools for cheese production namely incubator, cheese cloth, cheese presses and pan, chemical (proximate) analysis apparatus such as soxlet, Kjeldahl, oven, and SDS-PAGE Electrophoresis.

\section{Production of Probiotic Starter}

Starters from isolates L. rhamnosus TW2 and L. plantarum TW14 were inoculated separately in MRSB media and incubated at $37^{\circ} \mathrm{C}$ for $24 \mathrm{~h}$ until the cells grows that was indicated by the increased turbidity. Then, $5 \%(\mathrm{v} / \mathrm{v})$ of the probiotic starter was added to the goat milk and incubated at $37^{\circ} \mathrm{C}$ for $6 \mathrm{~h}$ to produce a $10^{8} \mathrm{cfu} / \mathrm{mL}$ final concentration of starter that was examined by serial dilutions.

\section{Production of Goat Milk Cheese}

The cheese was produced by pasteurizing milk at $63^{\circ} \mathrm{C}$ for $30 \mathrm{~min}$, then the temperature was decreased to $37^{\circ} \mathrm{C}$. The pasteurized milk was then added starter with concentration according to treatments but in a constant ratio of 1:1 (v/v) of L. rhamnosus TW2 and L. plantarum TW14 and the mixtures were re-incubated at $37^{\circ} \mathrm{C}$ for 6 $\mathrm{h}$ to reach the $\mathrm{pH}$ of 6.1 . Afterwards, $0.06 \mathrm{ml} / \mathrm{L}$ of animal rennet was added and incubated at $37^{\circ} \mathrm{C}$ for $2 \mathrm{~h}$ to form gel. The gel was sliced and rested for 10-15 min for syneresis. Heating of the gel was conducted at $40^{\circ} \mathrm{C}$ for $30 \mathrm{~min}$ and then it was filtered to separate the whey to obtain the remaining matrix called curd, which was ripened at cool temperature $\left(5^{\circ} \mathrm{C}\right)$, without a package.

\section{Analysis of Chemical Characteristics of Goat Milk Cheese}

Procedure of chemical analysis of cheese. Cheese composition comprising water, protein, and fat contents was analyzed using standard method (AOAC [Association of Official Analytical Chemists], 2006).

\section{Procedure of measuring $\mathrm{pH}$ and acidity}

The $\mathrm{pH}$ of cheese. The $\mathrm{pH}$ of cheese produced was measured using glass-electrode $\mathrm{pH}$ meter (Hanna Instrument) for $10 \mathrm{~g}$ cheese pulverized with $10 \mathrm{~mL}$ distilled water (Shakeel-Ur-Rehman et al., 2003).

Free Fatty Acid (FFA). Determination of FFA in the goat cheese was conducted by titration of $\mathrm{NaOH} 0.1 \mathrm{~N}$ (Sudarmadji et al., 2007). First, ten grams of sample was placed in Erlenmeyer tube, added with $50 \mathrm{~mL}$ of $96 \%$ alcohol and $2 \mathrm{~mL}$ of pp. indicator. The solution was titrated with standardized $0.1 \mathrm{~N}$ until pink color appeared and rested for $30 \mathrm{~s}$.

Total Titratable Acidity (TTA). Determination of total titratable acidity in goat cheese was aimed to measure the 
amount of organic acid in the sample (Sudarmadji et al., 2007).

Proteolysis profile with electrophoresis. One gram of cheese was defatted by extracting with diethyl ether, dissolved in solution containing $1 \mathrm{~mL}$ of EDTA (1\%), 1 $\mathrm{mL}$ of natrium deoxycholic $(1 \%)$, and $5 \mathrm{~mL}$ of urea $(50 \%$. $\mathrm{w} / \mathrm{v})$. The $\mathrm{pH}$ of the solution was set at 7.0 and ripened at $4^{\circ} \mathrm{C}$ for $24 \mathrm{~h}$. Cellulose acetate electrophoresis of casein fraction was measured with electrophoresis unit. Buffer was made of $18 \mathrm{~g}$ Tris barbital-sodium barbital buffer ( $\mathrm{pH}$ 8.6-9.0) and acid blue stain $(100 \mathrm{~mL}$ acid blue colorant with $50 \%$ acetic acid). As much as $5 \mu \mathrm{L}$ of sample was put in well, and placed in an acetic cellulose plate for 10 s. Electrophoresis was performed at 185 volt for $15 \mathrm{~min}$ and the plate was soaked in acid blue stain for $25 \mathrm{~min}$ and the stain was removed with $5 \%$ trichloro acetic acid in three-time washing until the background turned white. The last cleansing was with mixed solution of methanol: glacial acetic acid: cleaning solution with a ratio of 70:30:4 $\mathrm{v} / \mathrm{v} / \mathrm{v}$. The cellulose plate was dried at $70^{\circ} \mathrm{C}$ for $8-10 \mathrm{~min}$. The dissolved-casein fraction was measured with the remaining total area.

\section{Experimental Design}

The experiment used a completely randomized design with a $4 \times 4$ factorial arrangement each with 3 replications. The first factor was the mixed concentration of probiotic starters of isolates L. rhamnosus TW2 and $L$. plantarum TW14 with 4 levels i.e., 2.5, 5.0, 7.5, and $10 \%$ $\mathrm{v} / \mathrm{v}$. The second factor was the duration of ripening at $5^{\circ} \mathrm{C}$ i.e., 0 (no ripening), 10, 20, and $30 \mathrm{~d}$.

\section{Statistical Analysis}

The obtained data were subjected to analysis of variance (ANOVA), followed by Duncan test for the difference among treatments (Software SPSS 17.0).

\section{RESULTS}

Cheese produced with the addition of mixed isolates of L. rhamnosus TW2 and L. plantarum TW14 produce $54.00 \pm 1.38 \%$ to $65.12 \pm 1.93 \%$ water content and is included into a soft cheese category (Table 1). The highest water content was observed in unripen cheese with the addition of $2.5 \%$ probiotic starter. However, the protein contents of cheese produced with the addition of $2.5 \%$ probiotic starter increased when the duration of ripening was $30 \mathrm{~d}$. The averaged fat contents in this research ranged from $4.05 \pm 0.50 \%$ to $29.03 \pm 1.76 \%$. The lowest fat content was observed in the cheese produced by addition of $2.5 \%$ probiotic starter without ripening and the highest fat content was observed in the cheese produced by addition of $2.5 \%$ probiotic starter with 20 days of ripening. Analysis of variance showed that the addition of starter up to $10 \%$ did not significantly affect ( $P>0.05$ ) cheese fat content, but $30 \mathrm{~d}$ duration of ripening and its interaction significantly increased $(\mathrm{P}<0.01)$ this parameter. Duncan test revealed that after $10 \mathrm{~d}$ of ripening, cheese had higher fat content and remained high during $30 \mathrm{~d}$ of ripening. The increased fat content during $30 \mathrm{~d}$ of ripening was related to the ability of the starter used to hydrolyze fat in cheese matrix; therefore it dissolved fat that was detected as cheese total fat.

The average of ash content was $1.74 \pm 0.20 \%$ to $3.09 \pm 0.07 \%$. The lowest level of ash content was observed in cheese produced with the addition of $7.5 \%$ probiotic starter with the duration of $10 \mathrm{~h}$ ripening. The

Table 1. Average percentages of water, protein, fat, and ash contents of goat milk cheese with different starter concentrations and durations of ripening process $(\%)$

\begin{tabular}{cccccc}
\hline \multirow{2}{*}{$\begin{array}{c}\text { Starter } \\
\text { concentration (\%) }\end{array}$} & $\begin{array}{c}\text { Duration of ripening } \\
\text { process (day) }\end{array}$ & Water & Protein & Fat & Ash \\
\cline { 3 - 6 } 2.5 & 0 & $65.12 \pm 1.93^{\mathrm{A}}$ & $10.76 \pm 1.31^{\mathrm{A}}$ & $4.05 \pm 0.50^{\mathrm{A}}$ & $2.28 \pm 0.27^{\mathrm{C}}$ \\
& 10 & $56.24 \pm 2.60^{\mathrm{B}}$ & $15.29 \pm 1.82^{\mathrm{B}}$ & $25.83 \pm 3.09^{\mathrm{B}}$ & $1.82 \pm 0.22^{\mathrm{A}}$ \\
& 20 & $54.00 \pm 1.38^{\mathrm{B}}$ & $18.74 \pm 1.13^{\mathrm{B}}$ & $29.03 \pm 1.76^{\mathrm{B}}$ & $2.41 \pm 0.14^{\mathrm{A}}$ \\
& 30 & $54.06 \pm 0.76^{\mathrm{B}}$ & $18.47 \pm 0.61^{\mathrm{B}}$ & $27.24 \pm 0.91^{\mathrm{B}}$ & $1.79 \pm 0.06^{\mathrm{AD}}$ \\
5.0 & 0 & $62.87 \pm 0.68^{\mathrm{A}}$ & $12.66 \pm 0.47^{\mathrm{A}}$ & $9.10 \pm 0.34^{\mathrm{A}}$ & $3.03 \pm 0.11^{\mathrm{BC}}$ \\
& 10 & $56.44 \pm 1.32^{\mathrm{B}}$ & $16.50 \pm 0.99^{\mathrm{B}}$ & $23.71 \pm 1.43^{\mathrm{B}}$ & $1.86 \pm 0.11^{\mathrm{B}}$ \\
& 20 & $56.52 \pm 0.76^{\mathrm{B}}$ & $16.63 \pm 0.58^{\mathrm{B}}$ & $25.21 \pm 0.88^{\mathrm{B}}$ & $2.45 \pm 0.08^{\mathrm{BD}}$ \\
& 30 & $56.47 \pm 2.07^{\mathrm{B}}$ & $17.64 \pm 1.68^{\mathrm{B}}$ & $25.41 \pm 2.42^{\mathrm{B}}$ & $2.44 \pm 0.23^{\mathrm{B}}$ \\
& 0 & $62.78 \pm 2.23^{\mathrm{A}}$ & $12.08 \pm 1.47^{\mathrm{A}}$ & $15.28 \pm 1.86^{\mathrm{A}}$ & $2.36 \pm 0.28^{\mathrm{AC}}$ \\
& 10 & $57.72 \pm 1.53^{\mathrm{B}}$ & $16.24 \pm 1.87^{\mathrm{B}}$ & $21.51 \pm 2.49^{\mathrm{B}}$ & $1.74 \pm 0.20^{\mathrm{A}}$ \\
& 20 & $56.79 \pm 2.83^{\mathrm{B}}$ & $16.87 \pm 2.19^{\mathrm{B}}$ & $21.90 \pm 2.86^{\mathrm{B}}$ & $2.19 \pm 0.28^{\mathrm{AD}}$ \\
& 30 & $56.98 \pm 2.13^{\mathrm{B}}$ & $15.49 \pm 1.51^{\mathrm{B}}$ & $23.14 \pm 2.26^{\mathrm{B}}$ & $1.99 \pm 0.19 \mathrm{~A}$ \\
& 0 & $61.80 \pm 0.63^{\mathrm{A}}$ & $13.60 \pm 0.45^{\mathrm{A}}$ & $16.69 \pm 0.56^{\mathrm{A}}$ & $2.09 \pm 0.07^{\mathrm{AC}}$ \\
& 10 & $55.68 \pm 3.13^{\mathrm{B}}$ & $16.77 \pm 2.40^{\mathrm{B}}$ & $25.52 \pm 3.65^{\mathrm{B}}$ & $1.92 \pm 0.27^{\mathrm{A}}$ \\
& 20 & $56.20 \pm 0.82^{\mathrm{B}}$ & $16.46 \pm 0.62^{\mathrm{B}}$ & $25.43 \pm 0.97^{\mathrm{B}}$ & $2.09 \pm 0.75^{\mathrm{AD}}$ \\
& 30 & $56.67 \pm 1.70^{\mathrm{B}}$ & $17.43 \pm 1.37^{\mathrm{B}}$ & $23.03 \pm 1.81^{\mathrm{B}}$ & $2.21 \pm 0.17^{\mathrm{A}}$ \\
\hline
\end{tabular}

Note: Means in the same column with different superscripts differ very significantly $(\mathrm{P}<.0 .01)$. 
highest level of ash content was found in cheese processed with the addition of $5.0 \%$ probiotic starter prior to or without ripening. Analysis of variance showed that the addition of mixed starter of L. rhamnosus TW2 and L. plantarum TW14 and the duration of ripening significantly significantly increased ash content of cheese. Total ash content upon $30 \mathrm{~d}$ of ripening was 3.09\% that was lower than $4.37 \%$ reported by previous study (Dervisoglu \& Aydemir, 2007).

\section{Average $\mathrm{pH}$ Value of Cheese}

Cheese products from several mixtures of isolate starters of L. rhamnosus TW2 and L. plantarum TW14 and ripened for $30 \mathrm{~d}$ had $\mathrm{pH}$ values ranged from $4.97 \pm 0.13$ to $6.55 \pm 0.20$ (Table 2 ). The change in $\mathrm{pH}$ during cheese production and ripening process is one of the indications of $\mathrm{LAB}$ activity. Observation on cheese $\mathrm{pH}$ during ripening showed that the concentrations of probiotic starter did not affect $\mathrm{pH}$ value of cheese while the duration of ripening $(0,10,20$, and $30 \mathrm{~d})$ significantly decreased $(\mathrm{P}<0.05)$ the $\mathrm{pH}$ values of cheese produced. However, there was no interaction effect of concentrations of prebiotic starter and the duration of ripening was observed on the $\mathrm{pH}$ of cheese produced. Duration of ripening for $30 \mathrm{~d}$ decreased the $\mathrm{pH}$ of cheese, started from the $10^{\text {th }}$ day to the $30^{\text {th }}$ day. The lowest $\mathrm{pH}$ value was found in cheese processed with the addition of $7.5 \%$ probiotic starter with the duration of ripening of $30 \mathrm{~d}$, while the highest was found in that processed with $5.0 \%$ probiotic starter without ripening process (fresh).

\section{Total Titratable Acidity (TTA)}

Total Titratable Acidity (TTA) during 0 to $30 \mathrm{~d}$ of ripening showed that the highest average $(0.20 \pm 0.03)$ was found in cheese ripened for 20 and $30 \mathrm{~d}$, regardless of concentrations of probiotic starter. Regardless of the duration of ripening, the highest average of TTA $(0.17 \pm 0.07)$ was found in cheese processed with the addition of $2.5 \%$ prebiotic starter (Table 3 ). The concentration of probiotic starter used, as well as the duration of ripening process, significantly $(\mathrm{P}<0.01)$ increased the amount of TTA, but there was no interaction effect of those factors on the TTA $(\mathrm{P}>0.05)$. Lactic acid is a metabolite product from L. plantarum TW14 included in homofermentative LAB that produces dominant lactic acid (Setyawardani et al., 2011). Total titratable acidity increased after more than $10 \mathrm{~d}$ of ripening and the highest was found at the $20^{\text {th }} \mathrm{d}$. Ripened for 20 and $30 \mathrm{~d}$, cheese showed the highest bacteria population, namely 10.04 and $10.98 \mathrm{log} \mathrm{cfu} / \mathrm{g}$, respectively (unpublished data). The result was supported by the decreased $\mathrm{pH}$ level up to the $30^{\text {th }} \mathrm{d}$ of ripening. The result of TTA during $30 \mathrm{~d}$ ripening was $0.20 \pm 0.03$ that was lower than $2.38 \pm 0.03$ reported in traditional Kulek cheese (Dervisoglu \& Aydemir, 2007).

\section{Free Fatty Acid (FFA)}

The duration of ripening process significantly increased $(\mathrm{P}<0.01)$ the FFA in all starter concentrations (Table 4). The lowest FFA level, was $0.19 \pm 0.02 \%$, found in unripen cheese and the level started to increase with the duration of $10 \mathrm{~d}$ ripening. The duration of ripening of 20 and $30 \mathrm{~d}$ had equal $0.52 \%$ to $0.57 \%$ FFA which started to increase after $10 \mathrm{~d}$. The increased FFA during ripening was also reported in Baladi goat cheese (Tabet et al., 2016).

Table 2. Average $\mathrm{pH}$ values of goat milk cheese with different starter concentrations and durations of ripening process

\begin{tabular}{cccccc}
\hline \multirow{2}{*}{$\begin{array}{c}\text { Starter } \\
\text { concentration (\%) }\end{array}$} & \multicolumn{5}{c}{ Duration of ripening process (day) } \\
\cline { 2 - 5 } Average \\
\hline 2.5 & 0 & 10 & 20 & 30 & $5.51 \pm 0.64$ \\
5.0 & $6.51 \pm 0.16$ & $5.42 \pm 0.20$ & $5.10 \pm 0.13$ & $5.03 \pm 0.20$ & $5.56 \pm 0.62$ \\
7.5 & $6.55 \pm 0.20$ & $5.51 \pm 0.08$ & $5.28 \pm 0.28$ & $5.05 \pm 0.00$ & $5.55 \pm 0.59$ \\
10 & $6.43 \pm 0.17$ & $5.52 \pm 0.08$ & $5.05 \pm 0.50$ & $5.05 \pm 0.07$ & $5.43 \pm 0.65$ \\
Average & $6.47 \pm 0.11$ & $5.53 \pm 0.20$ & $5.14 \pm 0.16^{\mathrm{c}}$ & $4.99 \pm 0.12^{\mathrm{d}}$ & \\
\hline
\end{tabular}

Note: Means in the same column with different superscripts differ significantly $(\mathrm{P}<0.05)$.

Table 3. Total titrable acidity (TTA) of goat milk cheese with different starter concentrations and durations of ripening process (\%)

\begin{tabular}{|c|c|c|c|c|c|}
\hline \multirow{2}{*}{$\begin{array}{c}\text { Starter } \\
\text { concentration }(\%)\end{array}$} & \multicolumn{4}{|c|}{ Duration of ripening process (day) } & \multirow{2}{*}{ Average } \\
\hline & 0 & 10 & 20 & 30 & \\
\hline 2.5 & $0.06 \pm 0.03$ & $0.15 \pm 0.02$ & $0.23 \pm 0.01$ & $0.21 \pm 0.01$ & $0.17 \pm 0.07^{\mathrm{A}}$ \\
\hline 5.0 & $0.06 \pm 0.01$ & $0.11 \pm 0.05$ & $0.19 \pm 0.02$ & $0.17 \pm 0.02$ & $0.13 \pm 0.07^{\mathrm{B}}$ \\
\hline 7.5 & $0.07 \pm 0.00$ & $0.11 \pm 0.04$ & $0.15 \pm 0.04$ & $0.19 \pm 0.03$ & $0.13 \pm 0.06^{\mathrm{B}}$ \\
\hline 10 & $0.07 \pm 0.00$ & $0.13 \pm 0.01$ & $0.19 \pm 0.05$ & $0.21 \pm 0.01$ & $0.15 \pm 0.07^{\mathrm{AB}}$ \\
\hline Average & $0.06 \pm 0.012^{\mathrm{A}}$ & $0.13 \pm 0.04^{\mathrm{B}}$ & $0.20 \pm 0.04^{\mathrm{C}}$ & $0.20 \pm 0.03^{C}$ & \\
\hline
\end{tabular}

Note: Means in the same row and column with different superscripts differ very significantly $(\mathrm{P}<0.01)$ 


\section{Cheese Proteolysis Profile}

Protein degradation did not occur in unripen cheese in band [1] (Figure 1). Band [2], after 10 days ripening, showed protein degradation and proteolysis of protein with molecular weight of 72, 55, and $43 \mathrm{kDa}$. Band [2] contained proteins with molecular weights of 34,17 , and $10 \mathrm{kDa}$, and the protein with molecular weight of $17 \mathrm{kDa}$ was not found during $30 \mathrm{~d}$ ripening in all treatments. The process was started with protein hydrolysis with the conversion of water insoluble and soluble peptides into free amino acids.

\section{DISCUSSION}

\section{Chemical Characteristic of Goat Cheese}

Cheese with high water content has more free water to be used by bacteria, either the beneficial (starter) or the environment contaminant. Cheese with high water content is not favorable because the water weakens the structure of casein tissue, therefore the produced cheese is less solid (Banks, 2007; Yasin \& Shalaby, 2013). The higher water content in cheese showed relatively low fat and protein contents (Jung et al., 2013). Water content in cheese decreases during the ripening period because of syneresis process inside the cheese. In 120 days of ripening, water content decreased from $50 \%$ to $39 \%$ particularly in the inner part that contained more water than the outer side (Dervisoglu \& Aydemir, 2007).

Starter and non-starter bacteria in cheese actively dissolve protein and peptide where LAB has a weak proteolysis capacity but proteinase can gradually digest protein into simple peptides and amino acids (Hayaloglu et al., 2004). The use of mixed culture increases soluble protein and releases higher amino acids on the first day after cheese processing The use of mixed cultures enhances the soluble protein and the release of amino acid that are occurred on the first day after the processing of cheese (Bezerra et al., 2016).

Casein is the most important part in the production of cheese for coagulation to form curd then processed into cheese. The lower proportion of $\alpha_{\mathrm{s} 1}$-casein in goat milk resulted in a softer curd milk as compared to those with higher $\alpha_{\mathrm{s} 1}$-casein (Thomann et al., 2008). Those differences were related to the processing technique and types of milk, but the effect on nutrient content of cheese product was still unknown (Raynal-Ljutovac et al., 2008).

Mineral content in cheese is observed from the ash, protein, and fat contents, and milk minerals such as calcium, phosphorus, and magnesium are concentrated in curd during coagulation process (Miller et al., 2006). According to Park (1990), ash content of goat milk cheese was higher in hard cheese than soft cheese. The

Table 4. Free fatty acid (FFA) values of goat milk cheese with different starter concentrations and durations of ripening process (\%)

\begin{tabular}{ccccc}
\hline \multirow{2}{*}{$\begin{array}{c}\text { Starter } \\
\text { concentration (\%) }\end{array}$} & \multicolumn{4}{c}{ Duration of ripening process (day) } \\
\cline { 2 - 5 } & 0 & 10 & 20 & $0.68 \pm 0.08$ \\
5.5 & $0.21 \pm 0.06$ & $0.43 \pm 0.04$ & $0.72 \pm 0.07$ & $0.51 \pm 0.22^{\mathrm{A}}$ \\
7.5 & $0.15 \pm 0.01$ & $0.31 \pm 0.01$ & $0.47 \pm 0.05$ & $0.45 \pm 0.09$ \\
10 & $0.19 \pm 0.02$ & $0.30 \pm 0.14$ & $0.38 \pm 0.08$ & $0.56 \pm 0.16$ \\
Average & $0.21 \pm 0.04$ & $0.36 \pm 0.03$ & $0.51 \pm 0.02$ & $0.60 \pm 0.09$ \\
\hline
\end{tabular}

Note: Means in the same row and column with different superscripts differ significantly $(\mathrm{P}<0.01)$.

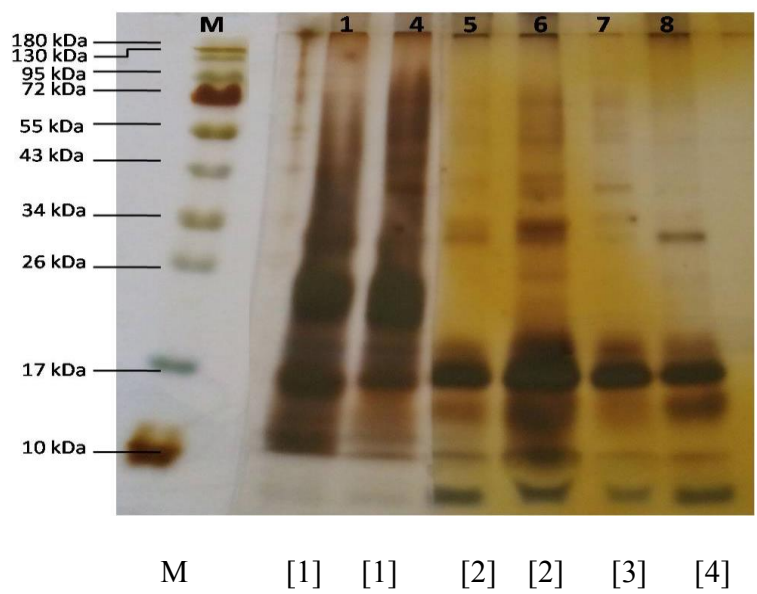

Figure 1. The proteolysis profile of cheese produced with starter Lactobacillus plantarum TW14 and L. rhamnosus TW2 during 30 days of ripening. M: Marker; [1] unripen goat cheese; [2] goat cheese ripened for 10 days; [3] goat cheese ripened for 20 days; [4] goat cheese ripened for 30 days. 
difference was due to varied mineral contents in the milk used for cheese production. A rapid acidification process by lactic acid followed by a rapid whey formation accelerates demineralization process, while a slow acidification with a rapid coagulation can protect mineral content in milk. Concentrations of $\mathrm{Ca}, \mathrm{P}, \mathrm{Na}$, and $\mathrm{Cl}$ were lower in soft cheese than hard cheese. The varied mineral content was assumed due to the different mineral contents in raw material and processing technique (Park, 1990).

\section{The $\mathrm{pH}$ of Goat Cheese during Ripening}

In addition to starter concentration, milk $\mathrm{pH}$ would affect the $\mathrm{pH}$ value of cheese product through enzymatic reaction and aggregation that lowered the stability of milk colloid (De Marchi et al., 2009). During ripening, LAB cheese are growing, developing, and producing metabolite in the form of lactic acid that can lower the $\mathrm{pH}$ of cheese produced. Low $\mathrm{pH}$ value during ripening process plays a role in creating a non-conducive environment for the growth and development of other bacteria particularly pathogenic and spoilage bacteria. The final $\mathrm{pH}$ value in the ripened cheese was $4.99 \pm 0.12$ that was in line with previous finding by $\mathrm{D}^{\prime}$ Amato et al. (2008) that cheese $\mathrm{pH}$ at the $30^{\text {th }}$ day ripening was 5.1. During the final stage of cheese-making process and the initial stage of cheese ripening, LAB form lactic acids. The $\mathrm{pH}$ of cheese produced was also affected by the degree of development of added microbes; therefore different percentages of LAB culture addition would result in varied $\mathrm{pH}$ decreases. The $\mathrm{pH}$ of cheese produced decreases during 60 days of ripening because lactic acid produced and the release of certain amino acids such as aspartate and glutamate affect the $\mathrm{pH}$ of cheese (Sallami et al., 2004). At the final stage of ripening, the $\mathrm{pH}$ of cheese did not increase, indicating the metabolic activities of the isolates; therefore lactic acid was still produced and accumulated that eventually decreased the $\mathrm{pH}$ of cheese produced.

\section{TTA of Goat Cheese during Ripening}

Total titratable acidity plays important role in all milk coagulation phases, including micelle aggregation rate of casein and rennet reactivity. Total titratable acidity also affects syneresis rate and determines how easy the milk will be turned into cheese. To produce cheese with premium quality, milk with low acidity (hypoacid milk) is generally unused because it produces cheese curd that is rheologically unwanted with its paste-like texture (Formaggioni et al., 2001).

Surono (2004) stated that lactic acid resulted from fermentation process was in either dissociated or undissociated form, depended on $\mathrm{pH}$ value. Total titratable acidity increased during the ripening process and this result was supported by the values of cheese $\mathrm{pH}$ that significantly changed, and cheese made from heated milk would experience $\mathrm{pH}$ decrease during ripening followed by the increased total titratable acidity.

\section{FFA Value of Goat Cheese during Ripening}

The increased FFA concentration showed an increase in lipolysis activity. FFA served as precursors for flavor components such as methyl ketone, ester and fatty acid lactone, and alcohol (McSweeney \& Sousa, 2000). Free fatty acids (FFA) were released during lipolysis along with the proteolysis components and products that were directly contributed to form the compounds that contribute to the flavor of the product. Lipolysis is defined as the accumulation of FFA during cheese ripening in which high FFA is released from triglyceride. Total FFA concentrations, both short-chain and longchain FFA, were related to the type and amount of lipase during the ripening process and cheese sensory characteristics (Londono et al., 2011). FFA value increased in cheese produced with the 20 days duration of ripening, indicating lipolysis process due to the activities of lipases derived from rennet, milk, or LAB. According to Melilli et al. (2004), lipolysis in cheese varied due to the different sources of lipase. Lipase can be derived from pregastric namely rennet paste, from milk, and from microbe. Lipase source is important during lipolysis in cheese. The other source of lipolysis is the use of salt during cheese salting (Lavasani et al., 2012).

FFA increase after lipolysis, and are catabolized into methyl ketones by microbe. Methyl ketones decrease secondary alcohol by reductive bacteria as a mechanism against toxicity (Molimard \& Spinnler, 1996). Methyl ketone and its derivatives played significant role as an aroma substance in soft cheese and ripened cheese (Gómez-Ruiz et al., 2002).

\section{Proteolysis Profile of Goat Cheese during Ripening}

SDS-PAGE molecular weight between 22 and 18.5 kDa was mostly $\beta$-CN peptide such as $\beta-\mathrm{CN}$ (f1-190) and $\beta-\mathrm{CN}$ (f29-207). Fragment $\kappa-\mathrm{CN}$ (f1-105) was dominated by $10-15 \mathrm{kDa}$ peptides. While the smaller one from $\beta$ - Cn fragments such as $\beta$-CN (f106-207) and $\beta$-CN (f108-207) and some $\alpha$ S2-CN had approximately 14-10 kDa. Cheese ripening is generally followed by the increased level of peptide hydrolysis into smaller peptide and amino acid. Intact protein tends to be lower after cool ripening for 28 days, but it is not significant and indicates a slow proteolysis in cheese (Hekken et al., 2005). The process of milk homogenization increases the proteolysis activities (Juan et al., 2016). The process of proteolysis during cheese ripening is started by the enzyme in milk (plasmin), rennet (pepsin and chymosin), and probiotic LAB. Enzyme activity would lower casein concentration $(\mathrm{CN})(\alpha s-1$. $\alpha \mathrm{s}-1$.and $\mathrm{k}-\mathrm{CN})$ in forming large-sized peptide and medium-sized peptide.

At the final stage of cheese ripening, primary and secondary proteolysis occur very rapidly, leading to 90\% degradation of as1-and b-casein (Diezhandino et al., 2015).

Peptide was then hydrolyzed by a proteolysis enzyme produced by microbe (LAB starter, nonstarter, and adjunct probiotic) into a smaller peptide and free amino acid (FFA) that produced cheese flavor. The products of proteolysis directly gives cheese flavor or served 
as a precursor substance of cheese flavor (Singh et al., 2003).

\section{CONCLUSION}

It is concluded that 30 days duration of ripening at $5^{\circ} \mathrm{C}$ was the main contributing factor to chemical characteristics of cheese including chemical properties, $\mathrm{pH}$, TTA, FFA, and proteolysis profile of probiotic goat cheese, while the concentration of mixed probiotics affected ash content, TTA and FFA of cheese.

\section{ACKNOWLEDGEMENT}

The author expressed sincere gratitude to Directorate General of Higher Education for the grant through National Strategic scheme in the year of 2014-2015.

\section{REFERENCES}

Albenzio, M., A. Santillo, M. Caroprese, A. Braghieri, A. Sevi, \& F. Napolitano. 2013. Composition and sensory profiling of probiotic Scamorza ewe milk cheese. J. Dairy Sci. 96: 2792-2800. https://doi.org/10.3168/jds.2012-6273

AOAC [Association of Official Analytical Chemists]. 2006. Official Method of Analysis. 15 ${ }^{\text {th }}$ Ed. Association of Official Analytical Chemists Inc., Virginia USA.

Banks, J. M. 2007. Flavour, texture and flavour defects in hard and semi-cheeses. In: P. L. H. McSweeney (ed.) Cheese Problems Solved. Woodhead Publishing Limited, Cambridge, England.

Bezerra, T. K. A., A. R. R. de Araujo, E. S. do Nascimento, J. E. de Matos Paz, C. A. Gadelha, T. S. Gadelha, M. T. B. Pacheco, R. d. C. R. do Egypto Queiroga, M. E. G. de Oliveira, \& M. S. Madruga. 2016. Proteolysis in goat "coalho" cheese supplemented with probiotic lactic acid bacteria. Food Chem. 196: 359-366. https://doi.org/10.1016/j. foodchem.2015.09.066

Choi, J., L. Sabikhi, A. Hassan, \& S. Anand. 2012. Bioactive peptides in dairy products. Int. J. Dairy 65: 1-12. https:// doi.org/10.1111/j.1471-0307.2011.00725.x

D'Amato, D., M. Sinigaglia, \& M. R. Corbo. 2008. Microbiological and physicochemical characterisation of Canestrello Pugliese cheese, a traditional Apulian cheese made from cows' milk. Aust. J. Dairy Technol. 63: 61.

Dantas, A. B., V. F. Jesus, R. Silva, C. N. Almada, E. Esmerino, L. P. Cappato, M. C. Silva, R. S. Raices, R. N. Cavalcanti, \& C. C. Carvalho. 2016. Manufacture of probiotic Minas Frescal cheese with Lactobacillus casei Zhang. J. Dairy Sci. 99: 18-30. https://doi.org/10.3168/jds.2015-9880

De Marchi, M., V. Bonfatti, A. Cecchinato, G. Di Martino, \& P. Carnier. 2009. Prediction of protein composition of individual cow milk using mid-infrared spectroscopy. Ital. J. Anim. Sci. 8: 399-401. https://doi.org/10.4081/ijas.2009. s2.399

Dervisoglu, M. \& O. Aydemir. 2007. Physicochemical and microbiological characteristics of Kulek cheese made from raw and heat-treated milk. World J. Microbiol. Biotechnol. 23: 451-460. https://doi.org/10.1007/s11274-006-9246-x

Diezhandino, I., D. Fernández, L. González, P. L. H. McSweeney, \& J. M. Fresno. 2015. Microbiological, physico-chemical and proteolytic changes in a Spanish blue cheese during ripening (Valdeón cheese). Food Chem. 168: 134-141. https://doi.org/10.1016/j.foodchem.2014.07.039

FAO/WHO. 2002. working group report on drafting guidelines for the evaluation of probiotics in food London, Ontario, Canada No. 30.

Formaggioni, P., M. Malacarne, A. Summer, E. Fossa, \& P. Mariani. 2001. Milk with abnormal acidity. VI. The role of phosphorus content and the rennet-coagulation properties of Italian Friesian herd milks. Annali della Facolta di Medicina Veterinaria, Universita di Parma 21: 261-268.

Gómez-Ruiz, J. Á., C. Ballesteros, M. Á. G. Viñas, L. Cabezas, \& I. Martínez-Castro. 2002. Relationships between volatile compounds and odour in Manchego cheese: comparison between artisanal and industrial cheeses at different ripening times. Le Lait 82: 613-628. https://doi.org/10.1051/ lait:2002037

Guidone, A., A. Braghieri, S. Cioffi, S. Claps, F. Genovese, G. Morone, F. Napolitano, \& E. Parente. 2015. Effect of adjuncts on microbiological and chemical properties of Scamorza cheese. J. Dairy Sci. 98: 1467-1478. https://doi. org/10.3168/jds.2014-8554

Hafeez, Z., C. Cakir-Kiefer, E. Roux, C. Perrin, L. Miclo, \& A. Dary-Mourot. 2014. Strategies of producing bioactive peptides from milk proteins to functionalize fermented milk products. Food Res. Int. 63, Part A: 71-80.

Hayaloglu, M. Guven, P. Fox, J. Hannon, \& P. McSweeney. 2004. Proteolysis in Turkish White-brined cheese made with defined strains of Lactococcus. Int. Dairy J. 14: 599610. https://doi.org/10.1016/j.idairyj.2003.12.008

Hekken, D., M. Tunick, \& Y. Park. 2005. Effect of frozen storage on the proteolytic and rheological properties of soft caprine milk cheese. J. Dairy Sci. 88: 1966-1972. https://doi. org/10.3168/jds.S0022-0302(05)72872-1

Juan, B., A. Zamora, J. M. Quevedo, \& A.-J. Trujillo. 2016. Physicochemical, microbiological and sensory profiles of fermented milk containing probiotic strains isolated from kefir. LWT-Food Science and Technology 69: 17-23. https:// doi.org/10.1016/j.lwt.2015.12.013

Jung, H. J., E. J. Ko, \& H. S. Kwak. 2013. Comparison of physicochemical and sensory properties between cholesterolremoved gouda cheese and gouda cheese during ripening. Asian-Australas. J. Anim. Sci. 26: 1773-1780. https://doi. org/10.5713/ajas.2013.13255

Korhonen, H. \& A. Pihlanto. 2006. Bioactive peptides: Production and functionality. Int. Dairy J. 16: 945-960. https://doi.org/10.1016/j.idairyj.2005.10.012

Lavasani, A. S., M. Ehsani, S. Mirdamadi, \& S. Mousavi. 2012. Study of proteolysis and lipolysis of probiotic Lighvan cheese. International Journal of AgriScience 2: 341-352.

Londono, M., J. U. Sepulveda, \& V. Higuera. 2011. Identification of volatile compounds, free amino acids through chromatography and sensory properties of the pasta filata cheeses known as momposino. Vitae 18: 261-269.

McSweeney, P. L. \& M. J. Sousa. 2000. Biochemical pathways for the production of flavour compounds in cheeses during ripening: A review. Le Lait 80: 293-324. https://doi. org/10.1051/lait:2000127

Melilli, C., D. M. Barbano, M. Manenti, J. M. Lynch, S. Carpino, \& G. Licitra. 2004. Lipolysis and proteolysis in ragusano cheese during brine salting at different temperatures*. J. Dairy Sci. 87: 2359-2374. https://doi.org/10.3168/ jds.S0022-0302(04)73358-5

Miller, G. D., J. K. Jarvis, \& L. D. McBean. 2006. Handbook of dairy foods and nutrition. CRC press. https://doi. org/10.1201/9781420004311

Molimard, P. \& H. Spinnler. 1996. Review: Compounds involved in the flavor of surface mold-ripened cheeses: Origins and properties. J. Dairy Sci. 79: 169-184. https://doi. org/10.3168/jds.S0022-0302(96)76348-8

Mushtaq, M., A. Gani, F. A. Masoodi, \& M. Ahmad. 2016. Himalayan cheese (Kalari/Kradi) - Effect of different probiotic strains on oxidative stability, microbiological, sensory 
and nutraceutical properties during storage. Food sci. technol. 67: 74-81. https://doi.org/10.1016/j.lwt.2015.11.039

Nagpal, R., P. Behare, R. Rana, A. Kumar, M. Kumar, S. Arora, F. Morotta, S. Jain, \& H. Yadav. 2011. Bioactive peptides derived from milk proteins and their health beneficial potentials: an update. Food Funct. 2: 18-27. https://doi. org/10.1039/C0FO00016G

Park, Y. 1990. Nutrient profiles manufactured in of commercial goat milk cheeses the United States. J. Dairy Sci. 73: 30593067. https://doi.org/10.3168/jds.S0022-0302(90)78993-X

Raynal-Ljutovac, K., G. Lagriffoul, P. Paccard, I. Guillet, \& Y. Chilliard. 2008. Composition of goat and sheep milk products: An update. Small Rumin. Res. 79: 57-72. https://doi. org/10.1016/j.smallrumres.2008.07.009

Sallami, L., E. Kheadr, I. Fliss, \& J. Vuillemard. 2004. Impact of autolytic, proteolytic, and nisin-producing adjunct cultures on biochemical and textural properties of Cheddar cheese. J. Dairy Sci. 87: 1585-1594. https://doi.org/10.3168/ jds.S0022-0302(04)73312-3

Setyawardani, T., W. Rahayu, R. Maheswari, \& N. Palupi. 2011. Identification and characterization of probiotic lactic acid bacteria isolated from indigenous goat milk. Anim. Prod. 13.

Setyawardani, T., W. P. Rahayu, R. R. A. Maheswari, \& N. S. Palupi. 2014. Antimicrobial activity and adhesion ability of indigenous lactic acid bacteria isolated from goat milk. Int. Food Res. J. 21: 959-964.
Shakeel-Ur-Rehman, N. Y. Farkye, \& B. Yim. 2003. Use of dry milk protein concentrate in pizza cheese manufactured by culture or direct acidification. J. Dairy Sci. 86: 3841-3848. https://doi.org/10.3168/jds.S0022-0302(03)73991-5

Singh, T. K., M. A. Drake, \& K. R. Cadwallader. 2003. Flavor of cheddar cheese: a chemical and sensory perspective. Compr Rev Food Sci F 2: 166-189. https://doi. org/10.1111/j.1541-4337.2003.tb00021.x

Sudarmadji, S., B. Haryono, \& Suhardi. 2007. Prosedur Analisa untuk Bahan Makanan dan Pertanian. Liberty, Yogyakarta.

Surono, I. S. 2004. Probiotik Susu Fermentasi dan Kesehatan. YAPMMI, Jakarta.

Tabet, E., N. P. Mangia, E. Mouannes, G. Hassoun, Z. Helal, \& P. Deiana. 2016. Characterization of goat milk from Lebanese Baladi breed and his suitability for setting up a ripened cheese using a selected starter culture. Small Rumin. Res. 140: 13-17. https://doi.org/10.1016/j. smallrumres.2016.05.011

Thomann, S., A. Brechenmacher, \& J. Hinrichs. 2008. Strategy to evaluate cheesemaking properties of milk from different goat breeds. Small Rumin. Res. 74: 172-178. https://doi. org/10.1016/j.smallrumres.2007.06.005

Yasin, N. M. N. \& S. M. Shalaby. 2013. Physiochemical and sensory properties of functional low fat cheesecake manufactured using cottage cheese. Ann. Agric. Sci. 58: 61-67. https://doi.org/10.1016/j.aoas.2013.01.009

Yasmin, A., M. S. Butt, A. Sameen, \& M. Shahid. 2013. Physicochemical and amino acid profiling of cheese whey. PJN 12: 455. https://doi.org/10.3923/pjn.2013.455.459 